\title{
ECONOMIC CONSEQUENCES OF FINANCIAL STABILITY VIOLATION OF WORLD AUTOMOTIVE CORPORATIONS
}

\author{
Sergyi Smerichevskyi ${ }^{1}$ \\ National Aviation University, Ukraine \\ Ihor Kryvoviaziuk ${ }^{2}$ \\ Lutsk National Technical University, Ukraine \\ Larysa Raicheva ${ }^{3}$ \\ International Humanitarian University, Ukraine
}

\begin{abstract}
The purpose of the paper is to determine the state of automotive corporations' financial stability and to generalize the consequences of its violation for their activity and the global economy as a whole. Methods. The theoretical and methodological basis of the research is the scientific works in the field of corporate finance management and strategic development that studied analysing and evaluating the financial stability of corporate companies, maintaining their financial stability in the medium and long term, official statistics data of United Nations Conference on Trade and Development, financial statements of corporations Toyota Motor Corporation (Japan), Mercedes-Benz (Germany), and Tesla Motors (USA), own research results. The methodological basis of the study is a set of general scientific and special methods used to achieve the research goal: theoretical generalization, analysis and synthesis - in studying the content of scientific works on the research of financial stability of corporate companies and maintaining their financial stability; observation to obtain primary information about the state of the world automotive market; the method of coefficient analysis and typing the situations - to assess the financial stability of automotive corporations; analytical in determining the economic consequences of financial stability violation of automotive corporations; causation - to obtain final conclusions. Results. This article deals with the development of automotive industry in the world. The financial stability of leading automotive corporations is evaluated. The economic consequences of financial stability violation of automotive corporations are summarized. Financial strategies to improve the financial stability of automotive corporations are proposed. Practical value. The results of the study may be useful to the United Nations Conference on Trade and Development, the financial management of Toyota Motor Corporation, Mercedes-Benz and Tesla Motors. Value/originality - the state of financial stability of automotive corporations is determined and the consequences of its violation for their activity and the world economy as a whole are generalized. Further research should be directed towards the development of project measures to improve the financial stability of automotive corporations in the world.
\end{abstract}

Key words: financial stability, evaluating, automotive development, corporation, economic consequences, financial strategy.

JEL Classification: C13, G32, L62

\section{Introduction}

Global changes in the economic situation encourage modern corporations to find ways to increase their financial stability. It becomes possible by studying the state of their operational and financial activities, identifying problems and exploring opportunities that can optimize the financial position. The activity of automotive corporations has a significant impact on the stability of the global economic situation, the financial stability violation of which may lead to negative fluctuations in

\footnotetext{
Corresponding author:

${ }^{1}$ Department of Marketing, National Aviation University.

E-mail: s_f_smerichevsky@ukr.net

${ }^{2}$ Department of Entrepreneurship, Trade and Stock Exchange Activity, Lutsk National Technical University.

E-mail: krivovyazuk-igor73@ukr.net

${ }^{3}$ Department of Business Administration and Corporate Security, International Humanitarian University.

E-mail: Larisa_1991@ukr.net
} 
the world's securities trading centres, and may lead to a crisis situation in the automotive market. That is why the study of the economic consequences of financial stability violation of the world automotive corporations is an important and current topic of the present.

The purpose of the research is to determine the state of automotive corporations' financial stability and to generalize the consequences of its violation for their activity and the global economy as a whole.

\section{Literature review}

The issue of financial stability research in the works of contemporary scholars is rather multifaceted and is often identified with the study of issues of maintaining financial stability. One of the reasons that lead to instability of the best corporations functioning is the rapid pace of economic growth of industrialized countries in the world. The reason is in the fact that economic growth is more closely connected with the rise of new corporations than with the prosperity of already existing large firms (Fogel, Morck, Yeung, 2003). This situation, as is stated in the paper (Güngör, Sümer, Özbekler, 2017), leads to increasing in debt to non-financial companies, increasing risk and increasing attention to the financial stability of the companies.

Among the innovations recommended for use in the study of the corporate companies' financial stability is the development of a JT index, which is based on a financial model that can explain the causes of a crash on a one-year plan horizon. Such a method is useful in making decisions based on the results of assessing the financial stability of the economy (Jakubík, Teplý, 2011). The analysing Latvian companies experience showed that not only internal but also external factors have a significant impact on the dynamics of their financial stability. In particular, it is important to take into account the impact of changes in legislation, information, the role of intellectual capital, the impact of outsourcing on the company stability (Koleda, Lāce, 2008). Also, for studying the state of the enterprise financial equilibrium, it is proposed to use a correlationregression analysis based on the construction of an economic and mathematical model and, as its components, we should choose the coefficient of equity capital mobility, the ratio of absolute liquidity, the ratio of cash and non-cash assets, the ratio of liabilities to own capital (Gudz, 2017). The effect of the financial leverage can also be used to assess the financial stability of corporations, which use credit resources (Grennan, Michaely, Vincent, 2017). The use of discriminatory models for analysing financial situation of manufacturing companies is important for predicting the threat of bankruptcy (Hur-Yagba, Okeji, Ayuba, 2015). In addition, it is expedient to use a normative approach to forecast changes in financial indicators (Fedorova, Timofeev, 2015).

In order to maintain financial stability in the medium and long term, the need to analyse the financial position of the company through working capital, namely, through the study of changes in the indicator "flowing capital" is emphasized (LĂPĂDĂ ŞI, CĂRUNTU, 2012). In a number of studies, to ensure the companies' financial stability, the expediency of using integrated risk management through the use of risk maps is substantiated and it ensures the elimination of development imbalances based on financial consulting (Vovchenko, Holina, Orobinskiy, Sichev, 2017).

At the same time, the activity of multinational corporations, which include world automotive corporations, must be in line with state policy and must be implemented within a coordinated system of metamanagement (Backer, 2010).

\section{Development of automotive industry in the world}

Automotive industry among different spheres of activity is considered as a "locomotive", which successful and economically stable activity determines the efficiency of related complexes and industries functioning. At the same time, it is one of the most important and dynamic sectors of the world economy.

Volumes of automotive products make up one-third of the world production. Among the world leaders in the automotive industry are China, Japan, Korea, Germany, and the United States. However, production is concentrated in many countries. Table 1 summarizes

Table 1

Dynamics of automotive products sales in the world in 2012-2016*

\begin{tabular}{|l|c|c|c|c|c|}
\hline \multicolumn{1}{|c|}{ Indicators } & 2012 & 2013 & 2014 & 2015 & 2016 \\
\hline Sales volume of automotive products in the world, mln. USD, incl.: & 1245533,3 & 1290175,4 & 1336153,0 & 1268729,0 & 1300794,7 \\
\hline - developing countries & 310770,7 & 330446,6 & 346057,3 & 336423,9 & 329969,8 \\
\hline - countries with transition economies & 8812,0 & 10030,2 & 8793,0 & 6019,9 & 6221,2 \\
\hline - highly developed countries & 925950,6 & 949968,5 & 981302,7 & 926285,2 & 964603,6 \\
\hline $\begin{array}{l}\text { Annual growth of sales volume of automotive products in the } \\
\text { world, mln. USD }\end{array}$ & - & 44642,1 & 45977,7 & $-67424,0$ & 32065,7 \\
\hline $\begin{array}{l}\text { Annual rate of change in the sales volume of automotive products } \\
\text { in the world, \% }\end{array}$ & - & 103,58 & 103,56 & 94,95 & 102,53 \\
\hline
\end{tabular}

* generalized according to the data of United Nations Conference on Trade and Development (2017) 
data on the volumes of sales of automotive products worldwide in 2012-2016.

The results of the study showed that the total sales volume of automotive products during 2012-2014 increased, due to increased demand for automotive products, as well as the development of production. The negative situation in 2015 is connected with the global engineering crisis in the world. The largest share in the total sales volume of automotive products belongs to highly developed countries. The smallest share falls on the countries with a transition economy, where the development of production is at the stage of formation. In 2015-2016, there is an increase in sales volumes of the products of the automotive complex.

The leading corporations in the global automotive market, whose sales exceeds a million cars, are the Volkswagen Group, Toyota Motor Corporation, General Motors, Renault Nissan, Hyundai Motors, Mercedes-Benz, Ford Motor Company, Tesla Motors, Fiat Auto, Honda, Daimler AG, PSA Peugeot Citroen, BMW, Suzuki Motor Corporation, Tata Motors.

Dynamics of sales volumes of cars by leading world corporations in 2015-2016 is presented in Figure 1.

In 2016, global sales of GM cars in the US reached 10 million cars. Over the past decade, China has become one of the main growth markets in the global automotive industry, with sales of about 24.4 million cars in 2016.

Among automotive corporations, it is appropriate to mention Toyota Motor Co. (Japan), MercedesBenz (Germany), and Tesla Motors (USA). These corporations occupy $32.4 \%$ of the world automobile market, constantly innovate, increase their own capital, and take care of improving their financial position. The net sales revenue in 2016 was: Toyota Motor
Corporation - \$233979 million, Mercedes-Benz $\$ 180434$ million, Tesla Motors - \$7000.1 million. Net profit for the same period was: Toyota Motor Corporation - \$21798.88 million, Mercedes-Benz \$10555.73 million, Tesla Motors - (-773.1) million dollars.

\section{Assessment of leading automotive corporations' financial stability}

The assessment of the financial stability of a corporation is based on the general characteristics obtained during diagnosis of automotive corporations' financial condition in the world. The main requirements for assessing financial stability are:

- adherence to the principle of dynamism determining a range of fluctuations of the evaluation index, relevant specified types of the economic system stability. The interpretation of assessment values suggests a grouping the enterprises according to the following situations: absolute financial stability, insignificant financial stability violation, significant financial stability violation, absolute financial instability;

- compliance with the principle of unity and integrity - the financial indicators should be reduced to a single indicator covering the main characteristics: available financial assets at disposal and liabilities of the corporation;

- following the principle of synergy - suggests, on the one hand, assessing zones of the optimal choice of sustainable development financing strategy, and on the other - its efficiency and risk.

To determine the indicator of the automotive corporation financial stability, we suggest using the following model:

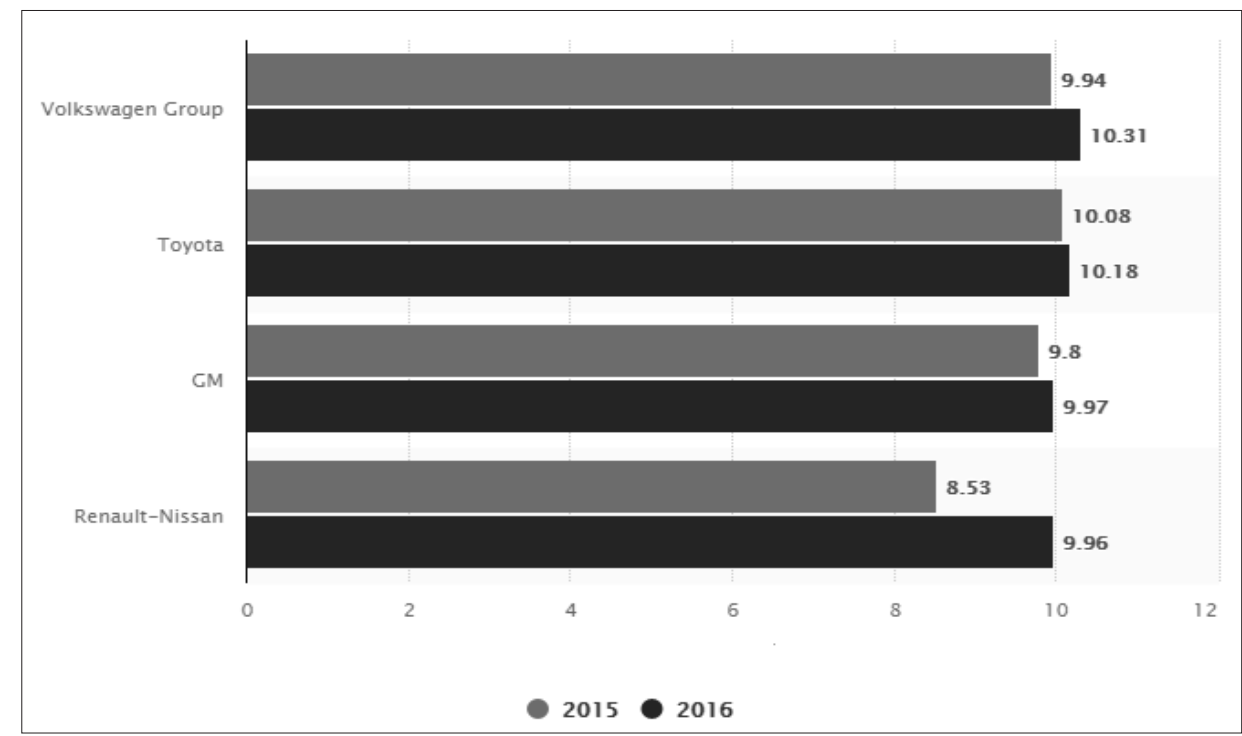

Fig. 1. Sales volumes by leading world automobile manufacturers in 2015-2016, million cars (Statista, 2017) 


$$
I_{f s}=\frac{F A}{G L},
$$

where $I_{f s}$ is an indicator of financial stability;

FA - financial assets of the corporation;

$G L$ - general liabilities of the corporation.

Table 2 proposes the main indicators of the components of automotive corporations' financial stability index.

Results of the study showed that the change of the financial stability indicator in Toyota Motor Corporation has the best dynamics; worse results are in Tesla Motors, whose financial stability index significantly reduced in 2017, the worst situation is in the Mercedes-Benz Corporation, which during all the investigated period did not reach a significant increase in financial stability.

We interpret the value of financial stability indicator to determine the type of situation in the corporations and the degree of compliance with its thresholds, using data in Table 3.

Comparing the results with the recommended limits of a particular type of financial situation, we can state that for Toyota Motor Corporation during 2014-2017, a slight violation of the corporation financial stability and the reason is a sufficiently large share of long-term liabilities; for Tesla Motors corporation, according to the analysis, it was found that the financial situation is very volatile and during the investigated period was within the "insignificant - significant" violation of financial stability; for the well-known German corporation Mercedes-Benz, the value of financial stability index was $0.532-0.565$, which corresponds to the state of absolute instability.

So, it can be said that there are significant violations of the financial stability of automotive corporations in the world.

\section{Consequences of financial stability violation of automotive corporations}

The activity of the world automotive corporations has a significant impact on the development of economic processes. Therefore, financial stability violation of automotive corporations can have economic consequences both for themselves and for the world economy:

Table 2

Dynamics of indicators of automotive corporations' financial stability *

\begin{tabular}{|c|c|c|c|c|}
\hline \multirow{2}{*}{$\begin{array}{l}\text { Components of integral } \\
\text { indicator }\end{array}$} & \multicolumn{4}{|c|}{ Value in the study period } \\
\hline & 2014 & 2015 & 2016 & 2017 \\
\hline \multicolumn{5}{|c|}{ Toyota Motor Corporation } \\
\hline 1. Financial assets, $¥$ million & 25693881 & 29231580 & 29044233 & 29540855 \\
\hline 2. General liabilities, $¥$ million & 26218486 & 30082501 & 29339411 & 30081233 \\
\hline Financial stability indicator & 0,980 & 0,972 & 0,990 & 0,982 \\
\hline \multicolumn{5}{|c|}{ Mercedes-Benz } \\
\hline 1. Financial assets, $€$ million & 77145 & 91847 & 102052 & 106735 \\
\hline 2. General liabilities, $€$ million & 145051 & 162542 & 183855 & 190291 \\
\hline Financial stability indicator & 0,532 & 0,565 & 0,555 & 0,561 \\
\hline \multicolumn{5}{|c|}{ Tesla Motors } \\
\hline 1. Financial assets, \$ million & 4020,24 & 4689,13 & 16304,97 & 18266,35 \\
\hline 2. General liabilities, \$ million & 4860,76 & 6961,47 & 16750,17 & 23022,98 \\
\hline Financial stability indicator & 0,827 & 0,674 & 0,973 & 0,793 \\
\hline
\end{tabular}

* Calculated by the author according to financial reporting data (Toyota Motor Corporation, Mercedes-Benz, Tesla Motors, 2014-2017).

Table 3

Interpretation of indicator values of corporations financial stability*

\begin{tabular}{|l|c|c|l|}
\hline \multicolumn{1}{|c|}{ Type of situation } & $\begin{array}{c}\text { Integral indicator } \\
\text { value }\end{array}$ & $\begin{array}{c}\text { Magnitude of negative } \\
\text { deviation from optimum } \\
\text { value }\end{array}$ & \multicolumn{1}{|c|}{$\begin{array}{c}\text { Degree of compliance of financial stability } \\
\text { characteristics with the threshold value }\end{array}$} \\
\hline Absolute financial stability & $>1,000$ & - & $\begin{array}{l}\text { Available financial assets are fully sufficient to repay } \\
\text { the general liabilities of the corporation (both current } \\
\text { and long-term). }\end{array}$ \\
\hline $\begin{array}{l}\text { Insignificant violation of financial } \\
\text { stability }\end{array}$ & $0,850-1,000$ & $15 \%$ & $\begin{array}{l}\text { Available financial assets are sufficient to repay current } \\
\text { liabilities, and partly to repay long-term liabilities. }\end{array}$ \\
\hline $\begin{array}{l}\text { Significant violation of financial } \\
\text { stability }\end{array}$ & $0,650-0,850$ & $15-35 \%$ & $\begin{array}{l}\text { Available financial assets are fully sufficient to repay } \\
\text { only current liabilities. }\end{array}$ \\
\hline Absolute financial instability & $0-0,649$ & $\begin{array}{l}\text { Available financial assets are not enough to repay the } \\
\text { general liabilities of the corporation (both current } \\
\text { and long-term). }\end{array}$ \\
\hline
\end{tabular}

*The author's development 
1. Economic impacts for automotive corporations:

- decrease in activity profitability;

- deterioration of corporations solvency;

- lack of funds for business diversification;

- deterioration of the ability to counteract the threats of the internal and external environment;

- falling ratings and deterioration of the companies' image;

- in future, reducing opportunities to obtain the required amount of investment for activity development;

- falling corporate securities rates and increasing the number of speculative transactions with them.

2. Economic consequences for the world economy:

- the negative fluctuations in the world trading centres of securities caused by changes in the rates of securities and a decrease in their profitability;

- causing a crisis situation in the automotive market;

- aggravation of global competition in the automotive market.

Improving the financial stability of automotive corporations in the world is possible only by adjusting the financial development strategy.

Analysing the financial stability of Toyota Motor Corporation, we see that this corporation has a steady dynamic during the period of 2014-2017, indicating an effective implementation of the financial strategy, but with minor miscalculations. For the corporation, the implementation of the financial stabilization strategy by strengthening the competitive position and increasing the market share should be recommended.

The financial situation in Mercedes-Benz is characterized by catastrophic instability. Therefore, for it, we recommend the implementation of financial development strategy by investing in reproductive processes.

Concerning Tesla Motors corporation, its indicators show the steady instability of the financial system. For American corporation, we recommend the implementation of the financial development strategy by forming potential competitiveness.

\section{Conclusions}

This research is devoted to solving an important task determining the state of financial stability of automotive corporations and generalizing the consequences of its violation for their activities and the global economy as a whole.
Adetailed study of the content of scientific publications by modern scholars made it possible to establish that the fall in the economy is more closely connected with the operation of already existing large companies than newcomers. At the same time, their financial state depends on the timely detection of financial stability violation, and for this, a variety of methods and models are used, as well as for its preservation in the medium and long term. Analysis of the automotive industry development in the world during 2012-2016 showed the preservation of the annual growth of the industry by $2.53-3.58 \%$, except for 2015 , when the indicator reduced by $5.05 \%$. The largest share in the total volume of sales of automotive products belongs to highly developed countries.

Among the leading corporations are Toyota Motor Co. (Japan), Mercedes-Benz (Germany), and Tesla Motors (USA), with a market share of $32.4 \%$. Assessing these corporations financial stability during 20142017 by the method of coefficient analysis and further typification of the situations gave the following results: for Toyota Motor Corporation, there is a slight violation of financial stability; Tesla Motors is characterized by a lack of financial stability within the limits of "insignificant - significant"; for Mercedes-Benz, the value of the financial stability index corresponds to a state of absolute instability.

Financial stability violation of automotive corporations can lead to an aggregate of economic consequences: falling their solvency and profitability, falling ratings and deterioration of the image, instability of the securities exchange rate. In the world economy, it can lead to an aggravation of global competition, changes in prices for products of the automotive industry, negative fluctuations in securities exchange rates on the global stock market, crisis situations.

To improve the financial stability of automotive corporations, it is recommended to upgrade their financial strategies: for Toyota Motor Corporation by a method of strengthening the competitive position and increasing market share, for MercedesBenz - by investing into reproduction processes and for Tesla Motors - by a method of forming potential competitiveness.

Further research should be directed towards the development of project measures to improve the financial stability of automotive corporations in the world.

\section{References:}

Backer, L.C. (2010, August 13). Private Actors and Public Governance Beyond the State: The Multinational Corporation, the Financial Stability Board and the Global Governance Order. Indiana Journal of Global Legal Studies, Vol. 17. Retrieved from: https://ssrn.com/abstract $=1658730$.

Fedorova, E., \& Timofeev, Y. (2015). Standards of Financial Stability of Russian Companies: Industry-Specific Features. Journal of Corporate Finance Research, Vol. 9, No. 1, 38-47. Retrieved from: https://ssrn.com/ abstract $=3107810$.

Fogel, K., Morck, R., \& Yeung, B. (2003, April 1). Corporate Stability and Economic Growth. University of Alberta School of Business. Working paper. Retrieved from: https: //ssrn.com/abstract=412804. 
Global car sales by manufacturer in 2016 (February, 2017). Statista. Retrieved from: https://www.statista.com/ statistics/271608/global-vehicle-sales-of-automobile-manufacturers/.

Grennan, J., Michaely, R., \& Vincent, Ch.J. (2017, December 5). The Deleveraging of U.S. Firms and Institutional Investors' Role. Retrieved from: https://ssrn.com/abstract=1941902.

Gudz, T. (2017). Financial equilibrium as basis for enterprise's sustainable development: economic and mathematical foundation. Technology audit and production reserves, 5/4(37), 51-56.

Güngör, G.Y., Sümer, T.P., \& Özbekler, M.D. (2017). Corporate Sector Leverage From Financial Stability Perspective. IFC-ECCBSO-CBRT Conference on "Uses of Central Balance Sheet Data Offices' information". Özdereİzmir, Turkey, 26 September 2016, Vol. 45. Retrieved from: https://www.bis.org/ifc/publ/ifcb45k.pdf.

Hur-Yagba, A., Okeji, I., \& Ayuba, B. (2015). Analyzing Financial Health of Manufacturing Companies in Nigeria Using Multiple Discriminate Analysis. International Journal of Managerial Studies and Research, Vol. 3, No. 7, 72-81. Jakubík, P., \& Teplý, P. (2011). The JT index as an indicator of financial stability of corporate sector. Prague Economic Papers, 2, 157-176.

Koleda, N., \& Lāce, N. (2008). Key Factors of Financial Stability of Enterprises: Case from Latvia. In: Management, Economics and Business Development in the New European Conditions: VI International Scientific Conference, Czech Republic, 23-24 May, Brno: Brno University of Technology, 53-53.

Lăpăduși, M.L., \& Căruntu, C. (2012). The financial stability analysis through the working capital. Annals of the „Constantin Brâncuşi” University of Târgu Jiu, Economy Series, Issue 4, 146-153.

Mercedes-Benz (2018, April). Retrieved from: https://www.mercedes-benz.com/en/mercedes-benz/mercedesbenz-tv/.

Tesla Motors (2018, April). Retrieved from: https://www.tesla.com/.

Toyota Motor Corporation (2018, April). Retrieved from: http://www.toyota-global.com/.

United Nations Conference on Trade and Development (2017, April). Retrieved from: http://unctadstat.unctad. org/EN/Index.html.

Vovchenko, N.G., Holina, M.G., Orobinskiy, A.S., \& Sichev, R.A. (2017). Ensuring Financial Stability of Companies on the Basis of International Experience in Construction of Risks Maps, Internal Control and Audit. European Research Studies, Volume XX, Issue 1, 350-368. 